\title{
Acoustic communication and vocalization microhabitat in Ameerega braccata (Steindachner, 1864) (Anura, Dendrobatidae) from Midwestern Brazil
}

\author{
Forti, LR. ${ }^{\mathrm{a} *}$, Strüssmann, $C^{\mathrm{a}, \mathrm{b}}$ and Mott, $T^{\mathrm{a}, \mathrm{c}}$

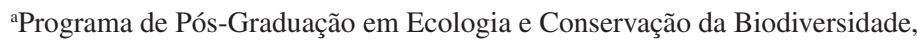 \\ Instituto de Biociências, Universidade Federal de Mato Grosso - UFMT \\ Av. Fernando Corrêa da Costa, s/n, CCBS-II, Boa Esperança, CEP 78060-900, Cuiabá, MT, Brazil \\ bDepartamento de Ciências Básicas e Produção Animal, Faculdade de Agronomia e Medicina Veterinária - UFMT \\ 'Programa de Pós-Graduação em Ecologia e Conservação da Biodiversidade, \\ Universidade Federal de Mato Grosso - UFMT \\ Av. Fernando Corrêa da Costa, s/n, CCBS-II, Boa Esperança, CEP 78060-900, Cuiabá, MT, Brazil \\ *e-mail: lucas_forti@yahoo.com.br
}

Received November 19, 2008 - Accepted February 11, 2009 - Distributed February 28, 2010

(With 5 figures)

\begin{abstract}
Ameerega braccata is an aposematic, small dendrobatid anuran known from its type-locality, Chapada dos Guimarães, in the State of Mato Grosso, and from a few additional localities in Mato Grosso do Sul and Goiás States, Brazil. The advertisement call of $A$. braccata is composed of a single unpulsed note, with a frequency range from 3.5 to $4.2 \mathrm{KHz}$ $(\mathrm{N}=110)$, and average duration of $65.8 \mathrm{~ms}(\mathrm{~N}=110, \mathrm{SD}=11.6)$. The territorial call is composed of five or six repeated notes, structurally similar to advertisement call notes. The courtship call is emitted in close-range interactions between male-female during the courtship event and may reach frequencies of 2.2 to $5.3 \mathrm{KHz}(\mathrm{N}=10)$, with shorter notes (average duration $43 \mathrm{~ms} ; \mathrm{N}=10 ; \mathrm{SD}=4.9)$. Call duration, note duration and call rate of the advertisement call showed high variation $(>15 \%$ of coefficient of variation), and dominant frequency showed low variation $(<4 \%)$. The properties with higher variation possibly respond to climatic features and male social position. When producing advertisement calls, males were usually found at an average height of $31.4 \mathrm{~cm}(\mathrm{~N}=19, \mathrm{SD}=12.2 \mathrm{~cm})$, mainly on leaves of shrubs and herbaceous plants (59\%). Individuals of A. braccata were found in open physiognomies in the Cerrado ("campo sujo" and "cerrado stricto sensu"), as opposed to that found by previous researchers, who reported an association of the species with gallery forests in the Cerrado.
\end{abstract}

Keywords: Amphibia, Dendrobatidae, Ameerega braccata, vocalization, habitat use.

\section{Comunicação acústica e microhabitat de vocalização em Ameerega braccata (Steindachner, 1864) (Anura, Dendrobatidae) do centro-oeste do Brasil}

\begin{abstract}
Resumo
Ameerega braccata é um pequeno anuro aposemático da família Dendrobatidae, conhecido de sua localidade-tipo, Chapada dos Guimarães, Mato Grosso e outras localidades adicionais em Mato Grosso do Sul e Goiás, Brasil. A vocalização de anúncio de A. braccata é composta de uma única nota, não pulsionada, com amplitude de frequência entre $3,5 \mathrm{e} \mathrm{4,2} \mathrm{KHz}$ $(\mathrm{N}=110)$ e duração média de $65,8 \mathrm{~ms}(\mathrm{~N}=110, \mathrm{DP}=11,6)$. A vocalização territorial é composta por cinco ou seis notas repetidas, estruturalmente similares às notas da vocalização de anúncio. Vocalização de corte é emitida em interações de proximidade entre machos e fêmeas durante o processo de corte, podendo alcançar frequências entre 2,2 e $5,3 \mathrm{KHz}$ $(\mathrm{N}=10$ ), com notas curtas (duração média $43 \mathrm{~ms} ; \mathrm{N}=10 ; \mathrm{DP}=4,9$ ). A duração do canto, a duração da nota e a taxa de repetição de canto de anúncio apresentam alta variação ( $>15 \%$ de coeficiente de variação), ao passo que a frequência dominante apresenta baixa variação $(<4 \%)$. As propriedades com variação alta podem variar de acordo com características climáticas e possivelmente em função do contexto social do macho emissor. Quando em exibição de anúncio, os machos foram usualmente encontrados a uma altura média de 31,4 cm $(\mathrm{N}=19, \mathrm{DP}=12,2 \mathrm{~cm})$, principalmente sobre folhas de arbustos e plantas herbáceas (59\%). Indivíduos de A. braccata foram encontrados em fisionomias abertas no cerrado ("campo sujo" e "cerrado stricto sensu"), em oposição aos relatos prévios, os quais registraram uma associação da espécie com floresta de galeria no cerrado.
\end{abstract}

Palavras-chave: Amphibia, Dendrobatidae, Ameerega braccata, vocalização, uso de habitat. 


\section{Introduction}

The production of sound in animals is generally used to advertise conspecifics (Duellman and Trueb, 1994; Lingnau and Bastos, 2003). In anurans, acoustic communication plays an essential role in reproductive biology (sensu Wells, 1977; Kanamadi et al., 1993). One main type of vocalization is the "advertisement call", emitted by males basically to attract females and to establish territories during breeding seasons (Wells, 1987; Hedges, 1987; Kelley, 2004). Because vocalization tends to be species-specific, it also plays an essential role in pre-zigotic reproductive isolation by reducing the chances of interspecific mating (Abrunhosa et al., 2001). It is also a remarkable and important tool for species identification (Guimarães and Bastos, 2003; Pombal-Júnior et al., 1995).

Other call types have been also recognised (Wells, 1987), including "courtship calls" (emitted by males in courtship context), "territorial calls" (emitted by males in response to invader males), "encounter calls" (emitted by males in close-range agonistic interactions with other males), "reciprocation calls" (emitted by females in courtship context), "release calls" (emitted by unreceptive males or females in response to amplexus), and "distress calls" (emitted by either sex, in response to disturbance) (Duellman and Trueb, 1994; Wells, 2007).

Microhabitats and perching sites selected for vocalization usually differ among species, and may be related to body-size and morphology (Bertoluci and Rodrigues, 2002). In complex communities, however, specific patterns of habitat occupation can be influenced also by the diversity of species sharing limited habitat resources in reproductive aggregations (Bertoluci and Rodrigues, 2002).

Herein we describe the physical structure of three kinds of calls (advertisement, territorial, and courtship calls) and vocalization microhabitat of individuals from a topotypical population of Ameerega braccata (Steindachner, 1864). This species belongs to the Dendrobatidae family, placed in the Ameerega picta (Bibron in Tschudi, 1838) group and is recorded for Cerrado habitats in Mato Grosso State, midwestern Brazil, and probably occurs in Bolivia and Paraguay (Frost, 2007). Besides the type-locality, Chapada dos Guimarães, in Mato Grosso, the species is presently known in a few additional localities in this State, and in the States of Mato Grosso do Sul and Goiás as well (Frost, 2007). Data of natural history of A. braccata are scarce and acoustic parameters have not been described yet (Haddad and Martins, 1994; IUCN, 2006).

\section{Materials and Methods}

Field observations were made from October 2007 to March 2008, in one locality in Chapada dos Guimarães municipality (15 $24^{\prime} \mathrm{S}$ and $55^{\circ} 50^{\prime} \mathrm{W}$; 650 m.a.s.l.), and another in Cuiabá municipality ( $15^{\circ} 20^{\prime} \mathrm{S}$ and $55^{\circ} 53^{\prime} \mathrm{W} ; 250$ m.a.s.l.), both in Mato Grosso State, Brazil. Mean annual precipitation in Chapada dos Guimarães ranges from 1800 to $2000 \mathrm{~mm}$ and mean temperature is $22.8^{\circ} \mathrm{C}$ in July, and $27.2^{\circ} \mathrm{C}$ in October (Pinto and Hay, 2005). In Cuiabá, the climate is semi-humid with mean annual temperature between
24 to $26^{\circ} \mathrm{C}$, mean annual precipitation ranges from 1250 to $1500 \mathrm{~mm}$ (Carvalho and Nogueira, 1998).

Vocalizations of 15 males were recorded ( 9 from Chapada dos Guimarães, and 6 from Cuiabá) under natural conditions with a Sony TCM 5000EV tape recorder and a directional YOGA EM 9600 microphone. From 15 males 11 advertisement call sequences were obtained, 4 territorial call sequences (during territorial disputes) and 1 courtship call sequence (during the courtship event). Recordings were made from a distance of approximately $50 \mathrm{~cm}$ from each male. The sound digitalisation, analysis and the ocillograms and Sonograms were made in Cool Edit 96 $6^{\mathrm{TM}}$ (Syntrillium), with a16 bits resolution and Fast Fourier Transformation (1024). For each male, 10 calls were analysed. Among these, we selected for our Figures 1 to 3 calls associated to temperature data, low levels of acoustic interference and acoustic parameters near the mean values recorded for the species. Seven recorded males were captured, three of them were collected (IBAMA license register number: 2075225) and deposited in the Coleção Zoológica da Universidade Federal de Mato Grosso (UFMT 7713, 7695, 7752).

Air temperature and relative humidity were taken with a digital termo-higrometer (Instrutherm). Snout-vent-length (SVL) of the individuals were obtained with a digital caliper (BTS) with precision of $0.01 \mathrm{~mm}$. The variation in the properties of the advertisement call was assessed using the Coefficient of Variation (CV) as suggested by Gerhardt and Huber (2002). The Coefficient of Variation was evaluated among individuals and inside individuals of $A$. bracatta.

Microhabitats used by calling males were described regarding the nature of the substratum and height above the ground, in the exact point where each animal was found.

\section{Results}

\subsection{Vocalizations}

Ocillograms and spectrograms of advertisement, territorial, and courtship calls of individuals of A. braccata (from Chapada dos Guimarães UFMT 7713 and Cuiabá UFMT 7695) are presented in Figures 1, 2 and 3, respectively. Acoustic parameters of each distinct call type are summarised in Table 1. Territorial calls are different from other call types mainly by having five to six notes. The courtship calls were recorded during male-female interactions and it has wider frequency range and shorter call duration than other call types.

In Table 2, a comparison of the advertisement call characteristics of four species in the genus Ameerega is presented.

Considering the advertisement calls among individuals, the call duration, note duration and call rate were above $15 \%$ of variation, and were variable than dominant frequency, minimum frequency and maximum frequency (Figure 4). Even at individual level, call or note duration were relatively variable properties, with mean of $7.15 \%$ $( \pm 5.68)$ of variation (Figure 5). Dominant frequency, minimum frequency and maximum frequency showed respectively mean of $0.54( \pm 0.23), 2.35( \pm 0.8)$ and $1.7( \pm 0.69)$ of variation at individual level. 


\subsection{Habitat}

Individuals of $A$. braccata were found in two open physiognomies of Cerrado: the "campo sujo" and "cerrado stricto sensu" (for a detailed description of these or other Cerrado physiognomies in the region of Chapada dos Guimarães, see Conceição, 2000). Among 22 reproductive males observed throughout the study period, the majority were observed calling on leaves of shrubs and herbaceous plants $(59 \%) ; 22 \%$ of the individuals were calling on the ground, $18 \%$ on termite mounds, and only $1 \%$ on tree trunks. Calling males were found at an average height of $31.4 \mathrm{~cm}$ above the ground $(\mathrm{N}=19, \mathrm{SD}=12.2 \mathrm{~cm})$.

\section{Discussion}

\subsection{Vocalizations}

We identified three different types of calls in A. braccata (advertisement, territorial and courtship calls). The advertisement call in this species is composed of single notes,
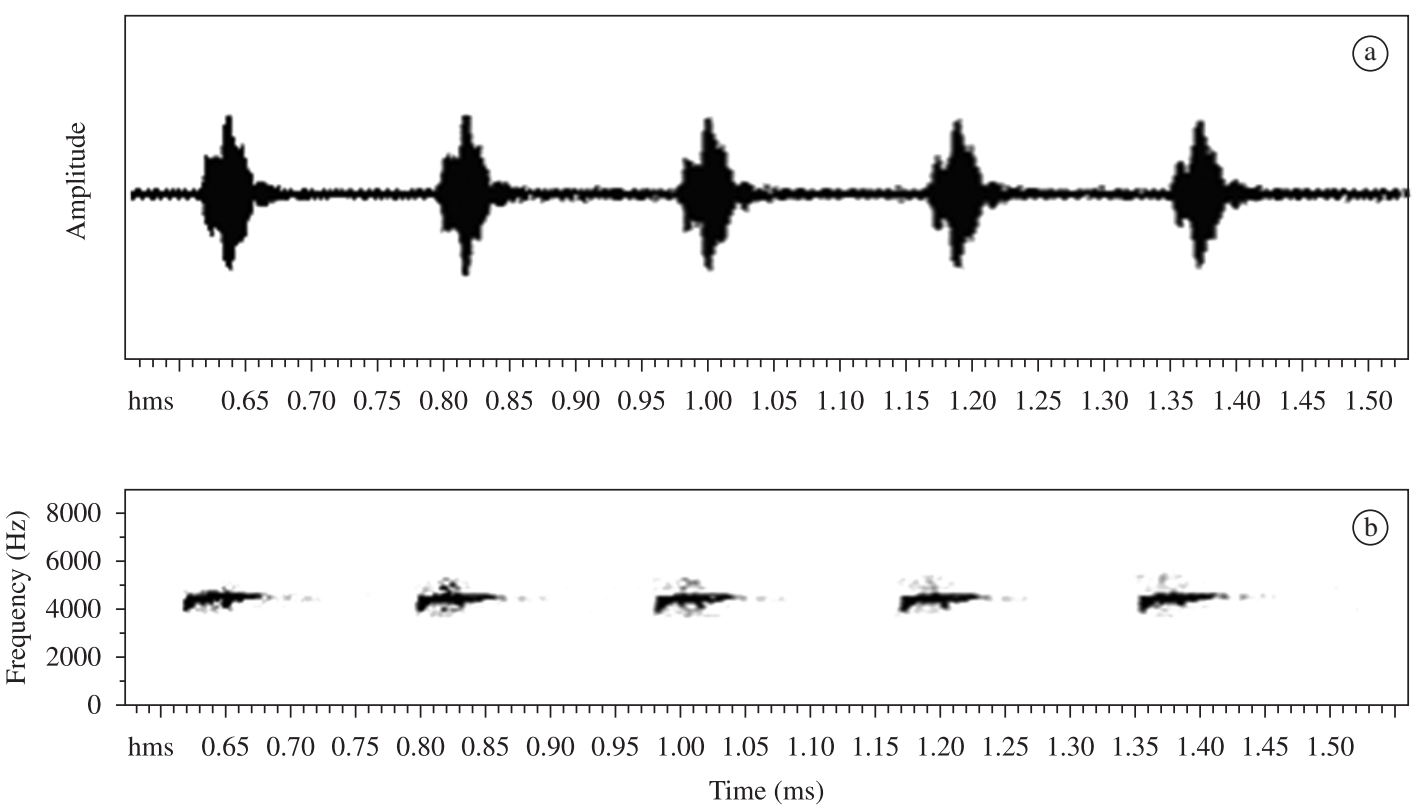

Figure 1. a) Ocillogram of the advertisement call of Ameerega braccata from Cuiabá, Mato Grosso, Brazil. b) Spectrogram of the advertisement call of the same individual of $A$. braccata (air temperature: $24.5{ }^{\circ} \mathrm{C}$; relative humidity: $92 \%$ ).
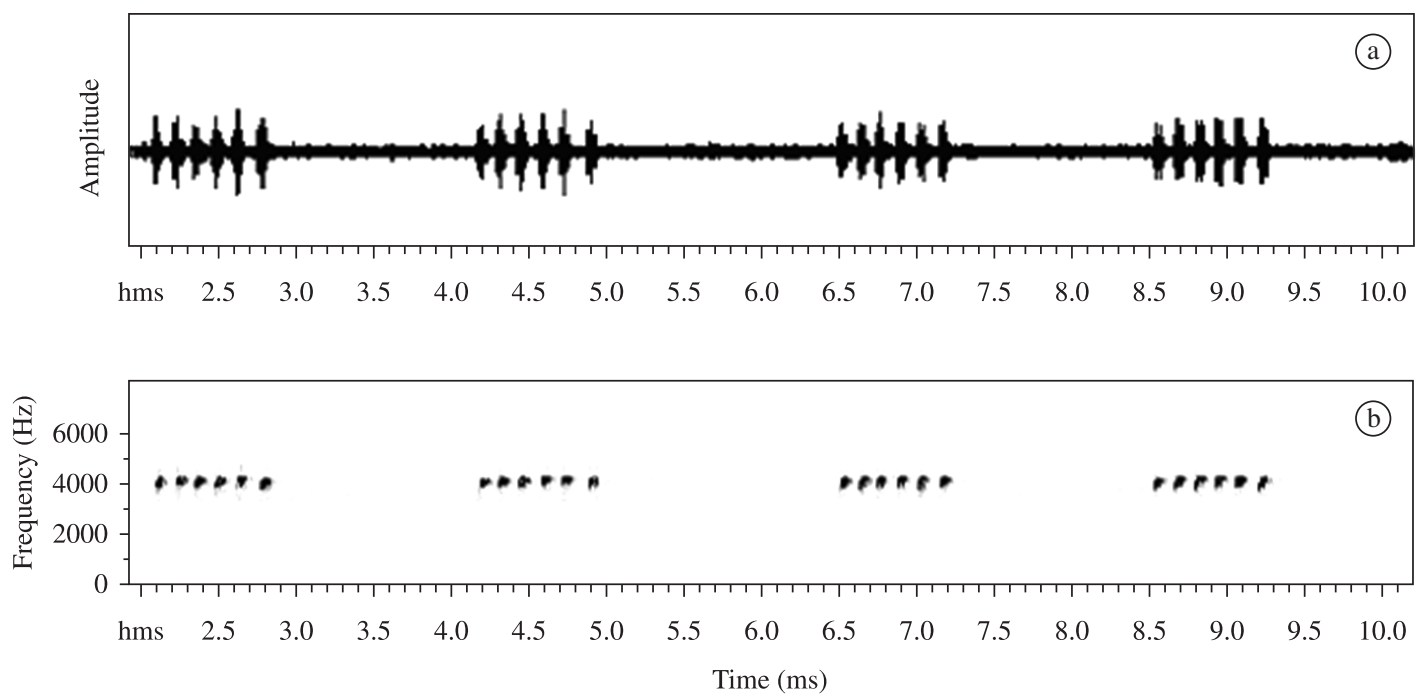

Figure 2. a) Ocillogram of the territorial call of Ameerega braccata from Chapada dos Guimarães, Mato Grosso, Brazil. b) Spectrogram of the territorial call of the same individual of $A$. braccata (air temperature: $25.0^{\circ} \mathrm{C}$; relative humidity: $87 \%$; $\mathrm{SVL}=22.4 \mathrm{~mm}$; mass $=0.75 \mathrm{~g}$ ). 

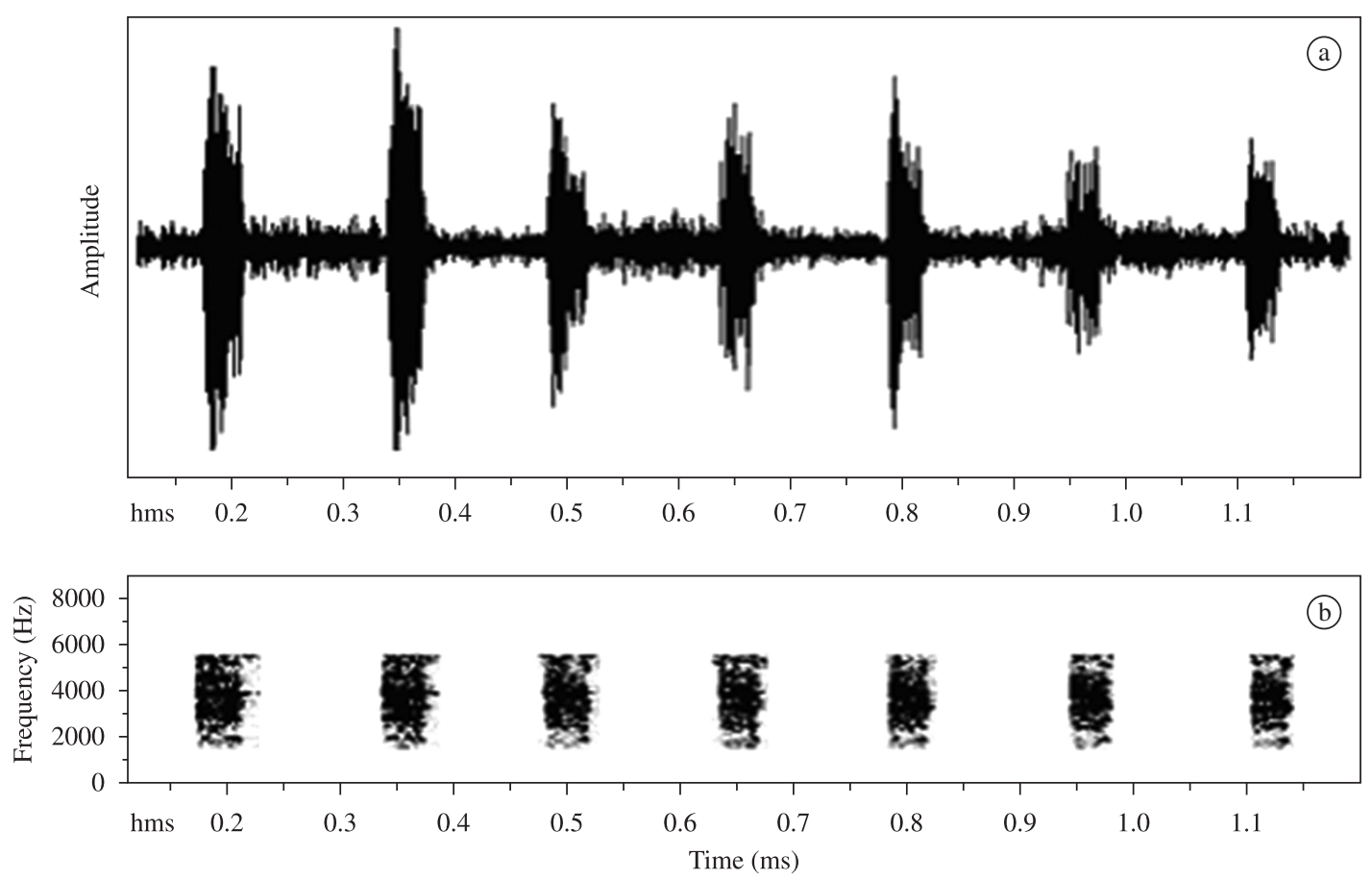

Figure 3. a) Ocillogram of the courtship call of Ameerega braccata from Cuiabá, Mato Grosso, Brazil. b) Spectrogram of the courtship call of the same individual of $A$. braccata (air temperature: $24.0^{\circ} \mathrm{C}$; relative humidity: $85 \% ; \mathrm{SVL}=23.1 \mathrm{~mm}$; mass $=1.0 \mathrm{~g}$ ).

Table 1. Mean values for selected acoustic parameters of three distinct types of vocalizations recorded from individuals of Ameerega braccata in the type-locality, Chapada dos Guimarães, and Cuiabá, Mato Grosso, Brazil. Call sample size (N), standard deviation $( \pm)$, range, and call rate sample size (n) are also indicated.

\begin{tabular}{lccc}
\hline \multicolumn{1}{c}{ Variable } & \multicolumn{3}{c}{ Call type } \\
\cline { 2 - 4 } & Advertisement call $(\mathbf{N}=\mathbf{1 1 0})$ & Territorial call $(\mathbf{N}=\mathbf{4 0})$ & Courtship call $(\mathbf{N}=\mathbf{1 0})$ \\
\hline Call duration $(\mathrm{ms})$ & $65.8( \pm 11.6,46-81.3)$ & $587.1( \pm 95.5,498.7-722.2)$ & $43( \pm 4.9,38-52)$ \\
Number of notes & 1 & 5 or 6 & 1 \\
Notes duration $(\mathrm{ms})$ & $65.8( \pm 11.6,46-81.3)$ & $66.2( \pm 11.5,49.1-72.8)$ & $43( \pm 4.9,38-52)$ \\
Pulses per note & 1 or 2 & 1 or 2 & 1 \\
Dominant frequency $(\mathrm{Hz})$ & $3986.4( \pm 151.4,3743.3-4205.2)$ & $4099.4( \pm 171.1,3861.2-4263.8)$ & $3734.2( \pm 51.7,3609.8-3778.8)$ \\
Minimum frequency $(\mathrm{kHz})$ & $3.5( \pm 0.17,3.2-3.8)$ & $3.5( \pm 0.18,3.2-3.67)$ & $2.25( \pm 0.2,2-2.7)$ \\
Maximum frequency $(\mathrm{kHz})$ & $4.2( \pm 0.12,4-4.4)$ & $4.37( \pm 0.2,4.1-4.6)$ & $5.31( \pm 0.4,4.4-5.8)$ \\
Call rate & $5.15( \pm 0.86,3.4-6.45)(\mathrm{n}=10)$ & $0.67( \pm 0.14,0.54-0.81)(\mathrm{n}=4)$ & $7(\mathrm{n}=1)$ \\
\hline
\end{tabular}

Table 2. Acoustic parameters of the advertisement call of Ameerega braccata (data from the present work), A. flavopicta, A. picta and A. hahneli. For the last three species, data are from Haddad and Martins (1994).

\begin{tabular}{|c|c|c|c|c|}
\hline \multirow[t]{2}{*}{ Variable } & \multicolumn{4}{|c|}{ Species } \\
\hline & Ameerega braccata & Ameerega flavopicta & Ameerega picta & Ameerega hahneli \\
\hline Call duration (ms) & $46-81$ & $480-630$ & $220-280$ & $150-300$ \\
\hline Number of notes & 1 & 6 & 4 & 6 \\
\hline Notes duration (ms) & 65.8 & 110 & 50 & 15 \\
\hline Pulses by note & 1 or 2 & 1 & 1 & 1 \\
\hline
\end{tabular}




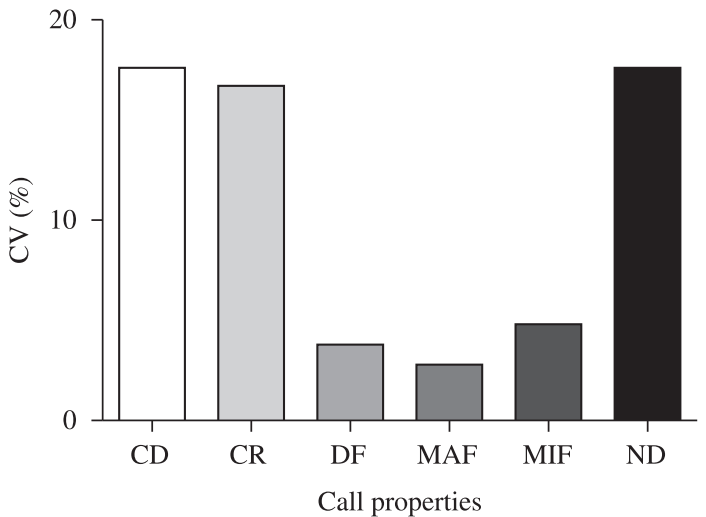

Figure 4. Intra-population coefficient of variation (\%) of selected properties of 110 advertisement calls of Ameerega braccata: (CD) call duration, $(\mathrm{CR})$ call rate, $(\mathrm{DF})$ dominant frequency, (MAF) maximum frequency, (MIF) minimum frequency and (ND) note duration.

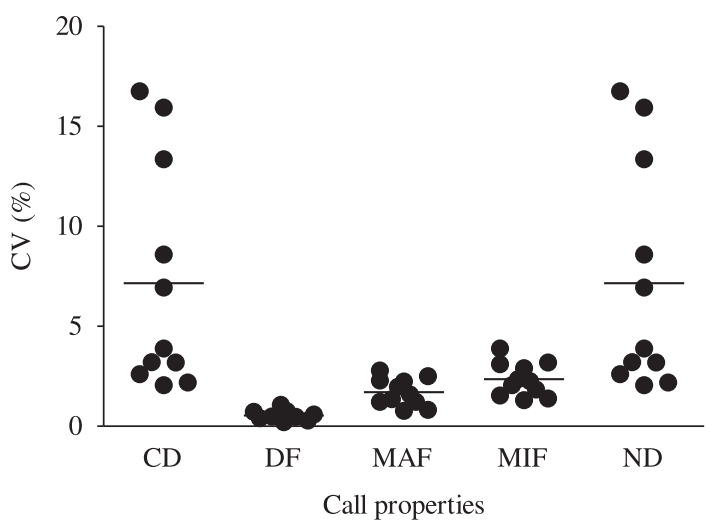

Figure 5. Intra-individual coefficient of variation (\%) of selected properties of 110 advertisement calls from 11 Ameerega braccata individuals: (CD) call duration, (DF) dominant frequency, (MAF) maximum frequency, (MIF) minimum frequency and (ND) note duration. The lines in the figure represent each mean value by property.

differing from A. picta, A. flavopicta (Lutz, 1925) and A. hahneli (Boulenger, 1884), whose males emit more than one note per call (Haddad and Martins, 1994; Table 2). The calls of A. hahneli have a wider frequency range (2.5 to 7.0 $\mathrm{KHz}$ ) than that of A. braccata $(3.5$ to $4.2 \mathrm{KHz})$, A. picta $(3.4$ to $4.3 \mathrm{KHz}$ ) and A. flavopicta (3.2 to $4.2 \mathrm{KHz}$ ). Additionally, the note duration of the A. hahneli call is shorter than A. braccata (Table 2) (Haddad and Martins, 1994).

The territorial call of A. braccata is similar to the advertisement call of $A$. flavopicta by having five or six notes per call. Nevertheless, mean duration is $587 \mathrm{~ms}$ in our sample, somewhat lower than that in A. flavopicta (Haddad and Martins, 1994).

In spite of the intensity not having been measured, the courtship call of A. braccata seemed to be lower than that of the other kinds of calls produced in this species. In a population of A. flavopicta from central Brazil, similar findings were reported by Toledo et al. (2004), who argued that the low intensity of courtship call may represent an adaptation to avoid detection of a newly formed reproductive pair by neighbouring males.

The high coefficients of variation for call properties such as call duration, call rate and note duration for both within the individual and the population for Ameerega braccata are in agreement with the common pattern of many anuran species calls (Gerhardt and Huber, 2002). In fact, these variables are more susceptible to variation with climatic features and male social context than acoustic parameters with lower coefficients of variation between individuals. Generally these properties that vary a lot are often the targets of the females' choice and also may be important for male territorial defense (Gerhardt, personal communication). Because it is a main property used in specific recognition, however, dominant frequency would be probably less subjected to within-population variation (Bernal et al., 2005). Nevertheless, dominant frequency may vary with body size (Bee, 2002; Smith et al., 2003), a relationship that must be investigated in further studies with $A$. braccata.

Previous studies on acoustic communication were basically descriptive; however, recent investigations have analysed acoustic features, also from evolutionary, ontogenetic, and behavioural perspectives (Kumar, 2003). Those studies have benefited from this integrative approach, because acoustic characteristics may shed light on phylogenetic relationships among species (Martins and Jim, 2004). Unfortunately, call data for each species of the genus Ameerega were not obtained in a standardised way, thus preventing statistical comparisons. Furthermore, we lack a phylogenetic hypothesis that includes all species of the picta group; thus, we cannot map the bioacoustic traits onto a phylogenetic hypothesis of the group in order to assess any evolutionary trend. Twomey and Brown (2008) described a new species of a Peruvian Ameerega species based mainly on molecular data. The vocalization properties were one of the most important traits to discriminate the new species. In their phylogenetic hypothesis, A. braccata was sister group of A. flavopicta, although the position of this group with the remaining species of Ameerega could not be inferred precisely. From our bioacoustic comparisons among some species of picta group, A. hahneli shows the most distinctive vocalization based on range frequency and note duration. We suggest that researchers should standardise the collection of bioacoustics data from several males (at least 10 males from each locality) and analyse at least 10 calls from each male, but this may change in accordance with the variation from each species.

\subsection{Habitat}

Contrary to the habitat description of Haddad and Martins (1994), we found individuals of A. braccata in Chapada dos Guimarães and Cuiabá in open physiognomies of "campo sujo" and "cerrado stricto sensu" rather than in gallery forests, in populations from Chapada dos Guimarães and Barra do Bugres (nowadays Porto Estrela). According to the same authors, males of congenerics usually vocalise 
over rocks near streams (A. flavopicta), amidst leaf litter (A. hahneli), and among dead tree branches on the leaf litter (A. picta), therefore differing from what was observed for A. braccata in its type-locality, with males usually observed calling on leaves of shrubs and herbaceous plants. Costa et al. (2006), believed that A. flavopicta was the unique species among the Dendrobatidae family known to occupy open areas subjected to high temperatures and low humidity, but in the present study we found that A. braccata occupy the same kind of area with a pattern of similar conditions.

Bertoluci and Rodrigues (2002) suggested that anuran species that congregate in a reproductive locale tend to segregate temporally the microhabitat occupation. A. braccata do not take part in microhabitat segregation with other anuran species, because like other dendrobatids (Wells, 1987) this species does not gather in a specific place to reproduce.

Acknowledgements - We thank Luiz Antônio Solino for help during the fieldwork, André Pansonato for helping with the bioacoustics analysis, Carlos A. Navas Iannini, Itamar Alves Martins and H. Carl Gerhardt for suggestions on previous versions of the manuscript. LRF and TM thank CAPES for financial support, Bolsista PRODOC / CAPES.

\section{References}

ABRUNHOSA, PA., WOGUEL, H. and POMBAL Jr., JP., 2001. Vocalizações de quatro espécies de anuros do estado do Rio de Janeiro, sudeste do Brasil (AMPHIBIA, HYLIDAE, LEPTODACTYLIDAE). Boletim do Museu Nacional, no. 472, p. 1-12.

BEE, MA., 2002. Territorial male bullfrogs (Rana catesbeiana) do not assess fight ability based on size-related variation in acoustic signals. Behavioral Ecology, vol. 13, no. 1, p. 109-124.

BERNAL, XE., GUARNIZO, C. and LÜDDECKE, H., 2005. Geographic variation in advertisement call and genetic structure of Colostethus palmatus (Anura: Dendrobatidae) from the Colombian Andes. Herpetologica, vol. 61, no. 4, p. 395-408.

BERTOLUCI, J. and RODRIGUES, MT., 2002. Utilização de habitats reprodutivos e micro-habitats de vocalização em uma taxocenose de anuros (Amphibia) da Mata Atlântica do sudeste do Brasil. Papéis Avulsos de Zoologia, vol. 42, no. 11, p. 287-297.

CARVALHO, MA. and NOGUEIRA, F., 1998. Serpentes da área urbana de Cuiabá, Mato Grosso: aspectos ecológicos e acidentes ofídicos associados. Cadernos de Saúde Pública, vol. 14, no. 4, p. $753-763$.

CONCEIÇÃO, PN., 2000. Os hábitats da área de influência do APM Manso. In ALHO, CJR., CONCEIÇÃO, PN., CONSTANTINO, R., SCHLEMMERMEYER, T., STRÜSSMANN, C., VASCONCELLOS., LAS., OLIVEIRA, DMM. and SCHNEIDER, M. (Eds.). Fauna Silvestre da região do rio Manso - MT. Brasília: IBAMA. p. 31-127.

COSTA, RC., FACURE, KG. and GIARETTA, AA., 2006. Courtship, vocalization, and tadpole description of Epipedobates flavopictus (Anura: Dendrobatidae) in Southern Goiás, Brazil. Biota Neotropica, vol. 6, no. 1, p. 1-9.

DUELLMAN, WE. AND TRUEB, L., 1994. Biology of amphibians. 2 ed. New York: Macgraw-Hill.670 p.

FROST, DR., 2007. Amphibian Species of the World: an Online Reference. Version 5.0. New York: American Museum of Natural History. Available from: <http://research.amnh.org/herpetology/ amphibia/index.php>. Access in: 21/03/2008.
GERHARDT, HC. and HUBER, F. 2002. Acoustic communication in insects and anurans: common problems and diverse solutions. Chicago e Londres: University of Chicago Press. 531 p.

GUIMARÃES, LDA. and BASTOS, RP., 2003. Vocalizações e interações acústicas em Hyla raniceps (Anura, Hylidae) durante a atividade reprodutiva. Iheringia, Série. Zoologia, vol. 93, no. 2, p. $149-158$.

HADDAD, CFB. and MARTINS, M., 1994. Four species of Brazilian poison frogs related to Epipedobates pictus (Dendrobatidae): taxonomy and natural history observations. Herpetologica, vol. 50, no. 3, p. 282-295.

HEDGES, SB. 1987. Vocalization and habitat preference of the Jamaican treefrog, Hyla marianeae (ANURA, HYLIDAE). Caribbean Journal of Science, vol. 23, no. 3/4, p. 380-384.

International Union for Conservation of Nature - IUCN, 2006. Global Amphibian. Cambridge: IUCN. Available from: <www. globalamphibians.org $>$. Access in: 06/05/2008.

LINGNAU, R. and BASTOS, RP., 2003. Vocalizações de duas espécies de anuros do sul do Brasil (AMPHIBIA: HYLIDAE). Arquivos do Museu Nacional, Rio de Janeiro, vol. 61, no. 3, p. 203-207.

MARTINS, IA. and JIM, J., 2004. Advertisement call of Hyla jimi and Hyla elianeae (ANURA: HYLIDAE) in the Botucatu region, São Paulo, Brazil. Revista Brasileira = Brazilian Journal Biology, vol. 63, no. 3B, p. 645-654.

PINTO, JRR. and HAY, JV., 2005. Mudanças florísticas e estruturais na comunidade arbórea de uma floresta de vale no Parque Nacional da Chapada dos Guimarães, Mato Grosso, Brasil. Revista Brasileira de Botânica, vol. 28, no. 3, p. 523-539.

POMBAL Jr., JP., BASTOS, RP. and HADDAD, CFB., 1995. Vocalizações de algumas espécies do gênero Scinax (Anura:Hylidae) do sudeste do Brasil e comentários taxonômicos. Naturalia, vol. 20, p. 213-225.

KANAMADI, RD., SCHNEIDER, H., HIREMATH, CR. and JIRANKALI, CS., 1993. Vocalization of the tree frog Polypedates maculatus (Racophoridae). Journal of Biosciences, vol. 18, no. 2, p 239-245.

KELLEY, DB., 2004. Vocal communication in frogs. Neurobiology of Behavior, vol. 14, p. 751-757.

KUMAR, A., 2003. Animal communication. Current Science, vol. 85 , no. 10 , p. $1398-1400$.

SMITH, MJ., OSBORNE, W. and HUNTER, D., 2003. Geographic variation in the advertisement call structure of Litoria verreauxii (ANURA: HYLIDAE). Copeia, vol. 4, p. 750-758.

TOLEDO, LF., GUIMARÃES, LD., LIMA, LP., BASTOS, RP. and HADDAD, CFB., 2004. Notes on courtship, egg-laying site, and defensive behavior of Epipedobates flavopictus (Anura, Dendrobatidae) from two mountain ranges of central and southeastern Brazil. Phyllomedusa, vol. 3, no. 2, p. 145-147.

TWOMEY, E. and BROWN, JL., 2008. A partial revision of the Ameerega hahneli complex (Anura: Dendrobatidae) and a new cryptic species from the East-Andean versant of Central Peru. Zootaxa, vol. 1757, p. 49-65.

Wells, KD., 1977. The social behavior of anuran amphibians. Animal Behaviour, vol. 25, p. 665-693.

1987. The courtship of frogs. In TAYLOR, TD. and GUTTMAN, SI. (Eds.). The reproductive biology of amphibians. New York: Plenum Press. p. 233-262.

, 2007. The ecology and behavior of amphibians. Chicago e Londres: University of Chicago Press. 1148 p. 